\title{
The Strawberry DNA Testing Handbook
}

Youngjae Oh

Department of Horticultural Sciences, IFAS Gulf Coast Research and Education Center, University of Florida, Wimauma, FL 33598

Jason D. Zurn and Nahla Bassil

U.S. Department of Agriculture-Agricultural Research Service, National Clonal Germplasm Repository, Corvallis, OR 97333

Patrick P. Edger

Department of Horticulture, Michigan State University, East Lansing, MI 48824

Steven J. Knapp

Department of Plant Sciences, University of California Davis, Davis, CA 95616

Vance M. Whitaker and Seonghee Lee

Department of Horticultural Sciences, IFAS Gulf Coast Research and Education Center, University of Florida, Wimauma, FL 33598

Additional index words. disease resistance, DNA marker, fruit quality, marker-assisted selection, next generation sequencing, SNP

\begin{abstract}
The availability of strawberry (Fragaria $\times$ ananassa) genomic resources has increased dramatically in recent years. Some of these resources are readily applicable to strawberry breeding programs for use in DNA-informed breeding. Information about these tests and how to interpret them is dispersed through numerous manuscripts or in the laboratories that use them routinely. To assist breeders in identifying tests available to their breeding program and in implementing them in their program, a compendium of strawberry DNA tests was created. This compendium is available for download from the Genome Database for Rosaceae (https://www.rosaceae.org/organism/Fragaria/x-ananassa?pane=resource-4). This resource will be updated continually as old tests are modified and new tests are created.
\end{abstract}

The development of new strawberry (Fragaria $\times$ ananassa) cultivars with improved flowering, fruit quality, and disease resistance is an ultimate goal for fruit breeders worldwide. Selective breeding has resulted in tremendous crop improvement, but even greater progress can be achieved with the use of new technologies, such as molecular markers (Peace, 2017). As genome sequences and modern genetic resources for fruit crops

Received for publication 18 July 2019. Accepted for publication 6 Sept. 2019.

This work was supported by the Florida Strawberry Research and Education Foundation (FSREF), the U.S. Department of Agriculture/National Institute of Food and Agriculture Specialty Crop Research Initiative project ("RosBREED: Combining Disease Resistance with Horticultural Quality in New Rosaceous Cultivars" under award no. 2014-51181-22378 and "Next-generation Disease Resistance Breeding and Management Solutions for Strawberry" under award no. 2017-51181-26833).

We thank all members of the strawberry genetics and breeding programs, and strawberry molecular genetics and genomics colleagues for their technical assistance.

Y.O. and J.D.Z. contributed equally to this manuscript.

S.L. is the corresponding author. E-mail: seonghee105@ ufl.edu. have become available, it is critical that these resources be used to develop practical tools for crop improvement. DNA tests are tools that help breeders predict traits of interest in parents and offspring, and how they will be inherited in future generations.

The RosBREED project (https://www. rosbreed.org), funded by U.S. Department of Agriculture (USDA)-Specialty Crop Research Initiative, focused on leveraging genetic information to improve eight rosaceous crops: apple, blackberry, peach, pear, rose, strawberry, sweet cherry, and tart cherry. For strawberry, these improvement efforts included the development of genomic resources, the discovery of quantitative trait loci (QTL), and the facilitation of DNA-informed breeding (DIB, also known as marker-assisted breeding). DNA-informed breeding helps breeders select potential cultivars while reducing the need to maintain plants long term and perform phenotypic trials for traits that are expensive or difficult to measure (Peace, 2017; van Geest, 2017). The DIB process involves extracting DNA from parents or offspring and running DNA tests that have been associated with desirable traits. The DNA tests implemented in DIB may be for a closely linked rare allele or a functional mutation within the causal gene for a trait, as exemplified in the work by Perrotte et al. (2016) and Zorrilla-Fontanesi et al. (2012). Ideally, the DNA tests are high throughput, accurate, low cost, and user friendly. These factors are especially important when a large number of samples need to be genotyped with limited resources and time. When implemented in a breeding program, DIB can enhance the efficiency, accuracy, and pace of breeding while reducing the cost. Implementing DIB enables breeders to identify and exploit the genetic potential in their programs and use their resources effectively.

The first RosBREED project, "RosBREED: Enabling Marker-assisted Breeding in Rosaceae" (Iezzoni et al., 2010), was initiated in 2009 and identified many important QTL for flowering, fruit quality, and disease resistance traits. The first $90 \mathrm{~K}$ Axiom $^{\circledR}$ single nucleotide polymorphism (SNP) array (Bassil et al., 2015), developed as part of the first RosBREED project, has been used as a high-throughput genotyping tool for QTL discovery in numerous strawberry programs worldwide (Anciro et al., 2018; Nellist et al., 2019; Roach et al., 2016; Verma et al., 2017). The second RosBREED project, "RosBREED: Combining Disease Resistance and Horticultural Quality in New Rosaceous Cultivars" (Iezzoni et al., 2016, 2017), built on the initial work by identifying diseaseresistant QTL and combining them with horticultural quality QTL. This was accomplished through the development and use of many DNA tests. Moreover, the genomic resources developed by the RosBREED projects also facilitated the development of many DNA tests by the international community. This article describes briefly the development of an online compendium of DNA markers for DIB called the Strawberry DNA Testing Handbook, created with RosBREED support for the benefit of strawberry breeders and geneticists worldwide.

\section{Rationale}

In recent years, a number of chromosome regions (loci) in strawberry have been identified that control flowering, fruit quality, and disease resistance traits in strawberry. DNA tests have been developed for many of these loci in octoploid strawberry. Many breeding programs have adopted DIB as part of their breeding process by either running the tests internally or outsourcing the work to companies providing diagnostic testing services. The initial optimization process, as well as the performance and interpretation of DNA tests, often require a skill set that might not be readily available in all laboratories (Peace, 2017). As such, we created the Strawberry DNA Testing Handbook as an easy-to-use resource. The purpose of the handbook is to distill information from primary literature related to the DNA tests, provide a starting point for test optimization, and assist in the interpretation of tests for informed breeding decisions. Overall, we hope this resource can serve as a training tool and troubleshooting guide for the implementation of existing DNA tests in strawberry breeding programs. To ensure availability, the handbook has been 
published at the Genome Database for Rosaceae (Jung et al., 2019) and can be downloaded as a Microsoft Word document (https://www.rosaceae.org/organism/Fragaria/ $\mathrm{x}$-ananassa?pane $=$ resource-4). As new DNA tests are published or old tests are modified or replaced, the authors will continually update the handbook to maintain its relevance and usefulness to the strawberry breeding community.

\section{Technical Information}

In the Strawberry DNA Testing Handbook, tests are organized by trait (e.g., fruit quality and disease resistance), the gene/ locus being tested, and the test being used. Numerous SNP-based high-resolution melting markers are available for both horticultural quality and disease resistance traits (Table 1). Electrophoresis-based tests are also listed for breeding programs without access to a real-time thermocycler (Table 1). Handbook is described in the same format: 1) background information, 2) technical details, 3) test interpretation, and 4) additional notes. The background information describes the trait and gene/QTL with which the test is associated, as well as the primary literature describing the test development and validation. Suggested reaction mixtures, primer sequences, and polymerase chain reaction protocols provided as a starting point for test optimization and troubleshooting are presented in the technical section. A description of how to interpret the test, positive and negative control cultivars (Table 2), and a picture of positive and negative results are shown in the interpretation section. Many of the strawberry cultivars that can serve as positive and negative controls for the tests are part of the USDA-Agriculture Research Service National Clonal Germplasm Repository (NCGR) Fragaria collection in Corvallis, OR. Leaves or runners of plants are available for distribution through the U.S. National Plant Germplasm System (https://npgsweb. ars-grin.gov/gringlobal/search.aspx?). The final section consists of additional notes and caveats surrounding the test. These notes consist of items such as known false-positive or false-negative strawberry cultivars, pathogen virulence information, or tips to help in optimization or multiplexing. To get the most out of each test, users should read the entire protocol before use to identify any caveats related to their testing needs.

\section{Future Strawberry Community Involvement}

As mentioned previously, the handbook will be updated as new tests are developed and validated. As such, there is much potential for future community involvement to maintain the usefulness of the handbook. The recent publication of the $F$. Xananassa genome (Edger et al., 2019) will likely spur the development of new DNA tests. Moreover, breeding programs are likely to have Each test in the Strawberry DNA Testing

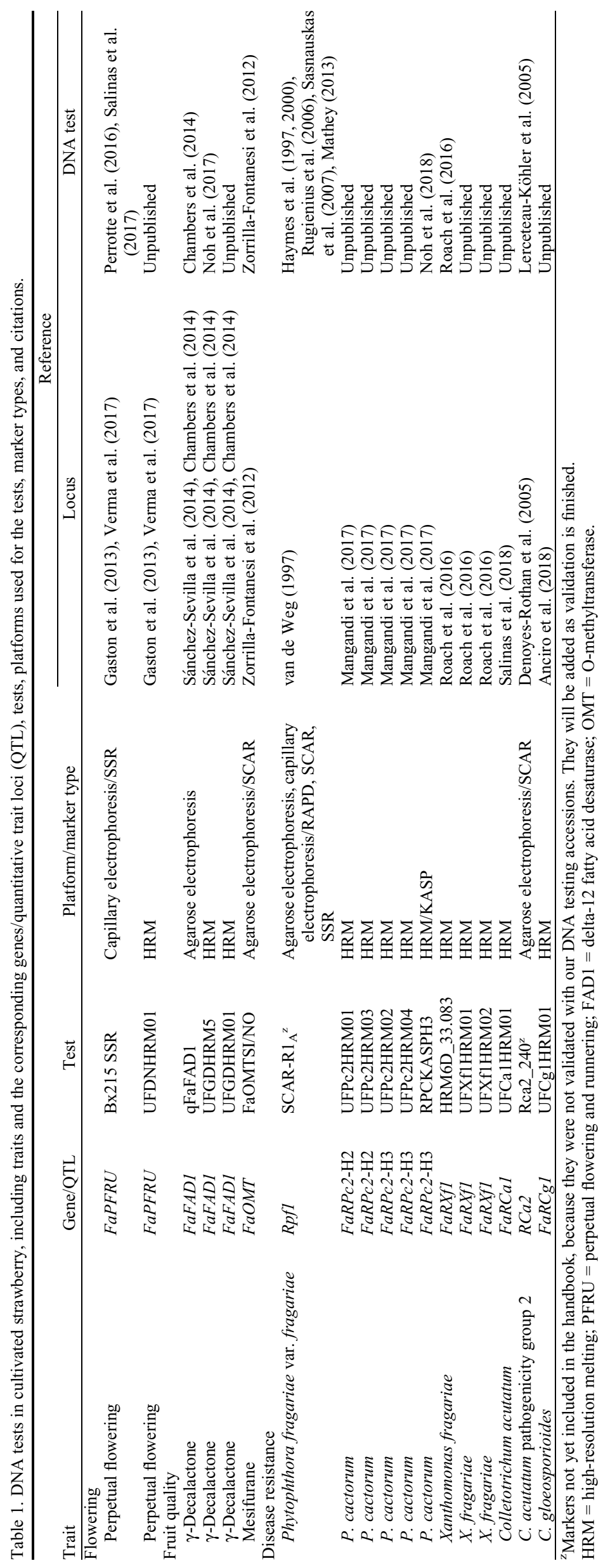


Table 2. Strawberry varieties found in the U.S. National Strawberry Collection at the National Clonal Germplasm Repository in Corvallis, OR, that can serve as positive $(+)$ and negative $(-)$ controls for some of the genes/quantitative trait loci presented in the DNA test handbook.

\begin{tabular}{|c|c|c|c|c|c|c|c|c|c|}
\hline Name & Accession & FaPFRU & FaFADI & $\mathrm{FaOMT}$ & FaRPc2-H2 & FaRPc2-H3 & FaRXf1 & FaRCal & FaRCgI \\
\hline Seascape & PI 660779 & + & - & - & - & + & - & - & - \\
\hline Selva & PI 551814 & + & - & & - & + & - & - & - \\
\hline Tribute & PI 551953 & + & + & - & - & + & - & + & - \\
\hline Camarosa & PI 670238 & - & - & + Het & - & + & - & - & - \\
\hline Charm & PI 664911 & - & - & & - & + & - & - & - \\
\hline Honeoye & PI 551588 & - & + & & - & + & - & + & - \\
\hline Jewel & PI 551927 & - & - & + Het & - & + & - & - & - \\
\hline Strawberry Festival & PI 664337 & - & + & + Het & - & + & - & - & - \\
\hline Sweet Charlie & PI 664317 & - & + & + Het & + & + & - & + & - \\
\hline Deutsch Evern & PI 551626 & - & - & - & + & - & - & + & + \\
\hline Hood & PI 551502 & - & - & - & - & + & - & + & - \\
\hline Earliglow & PI 551394 & $t^{z}$ & + & + Het & - & + & - & + & - \\
\hline Hecker & PI 551490 & + & - & & - & + & - & + & - \\
\hline Aromas & PI 684680 & + & + & & - & + & - & - & - \\
\hline Mara des Bois & PI 687353 & + & - & + & + & - & - & + & + \\
\hline US 4808 & PI 637937 & - & + & & - & - & + & - & - \\
\hline US 4809 & PI 637938 & - & + & & - & - & + & - & - \\
\hline
\end{tabular}

${ }^{\mathrm{z}}$ Earliglow does not have the day neutral phenotype, but is positive for the marker.

Het $=$ heterozygous marker genotype. Empty cells in FaOMT mean that the accessions were not tested.

regional positive and negative control cultivars they will discover as part of the testing process. Some of these cultivars might be publicly available as part of NCGR collection. To facilitate continued use of the handbook, we encourage feedback about use of these tests as well as information about new tests and potential control cultivars that the strawberry breeding and testing community can provide.

\section{Literature Cited}

Anciro, A., J. Mangandi, S. Verma, N. Peres, V.M. Whitaker, and S. Lee. 2018. FaRCg1: A quantitative trait locus conferring resistance to Colletotrichum crown rot caused by Colletotrichum gloeosporioides in octoploid strawberry. Theor. Appl. Genet. 131:2167-2177.

Bassil, N.V., T.M. Davis, H. Zhang, S. Ficklin, M. Mittmann, T. Webster, L. Mahoney, D. Wood, E.S. Alperin, U.R. Rosyara, H.K. Putten, A. Monfort, D.J. Sargent, I. Amaya, B. Denoyes, L. Bianco, T. van Dijk, A. Pirani, A. Iezzoni, D. Main, C. Peace, Y. Yang, V. Whitaker, S. Verma, L. Bellon, F. Brew, R. Herrera, and E. van de Weg. 2015. Development and preliminary evaluation of a $90 \mathrm{~K}$ Axiom ${ }^{\circledR}$ SNP array for the allo-octoploid cultivated strawberry Fragaria $\times$ ananassa. BMC Genomics 16:155.

Chambers, A.H., J. Pillet, A. Plotto, J. Bai, V.M. Whitaker, and K.M. Folta. 2014. Identification of a strawberry flavor gene candidate using an integrated genetic-genomic-analytical chemistry approach. BMC Genomics 15:217.

Denoyes-Rothan, B., G. Guérin, E. LerceteauKöhler, and G. Risser. 2005. Inheritance of a race-specific resistance to Colletotrichum acutatum in Fragaria $\times$ ananassa. Phytopathology 95:405-412.

Edger, P.P., T.J. Poorten, R. Van Buren, M.A. Hardigan, M. Colle, M.R. McKain, R.D. Smith, S.J. Teresi, A.D.D. Nelson, C.M. Wai, E.I. Alger, K.A. Bird, A.E. Yocca, N. Pumplin, S. Ou, G. Ben-Zvi, A. Brodt, K. Baruch, T. Swale, L. Shiue, C.B. Acharya, G.S. Cole, J.P. Mower, K.L. Childs, N. Jiang, E. Lyons, M. Freeling, J.R. Puzey, and S.J. Knapp. 2019. Origin and evolution of the octoploid strawberry genome. Nat. Genet. 51:541-547.

Gaston, A., J. Perrotte, E. Lerceteau-Köhler, M. Rousseau-Gueutin, A. Petit, M. Hernould, C. Rothan, and B. Denoyes. 2013. PFRU, a single dominant locus regulates the balance between sexual and asexual plant reproduction in cultivated strawberry. J. Expt. Bot. 64:1837-1848.

Haymes, K.M., B. Henken, T.M. Davis, and W.E. Van de Weg. 1997. Identification of RAPD markers linked to a Phytophthora fragariae resistance gene (RpfI) in the cultivated strawberry. Theor. Appl. Genet. 94:1097-1101.

Haymes, K.M., W.E. Van de Weg, P. Arens, J.L. Mas, B. Vosman, and A.P.M. Den Nijs. 2000. Development of SCAR markers linked to a Phytophthora fragariae resistance gene and their assessment in European and North American strawberry genotypes. J. Amer. Soc. Hort. Sci. 125:330-339.

Iezzoni, A, C. Peace, D. Main, N. Bassil, M. Coe, C. Finn, K. Gasic, J. Luby, S. Hokanson, J. McFerson, J. Norelli, M. Olmstead, V. Whitaker, and C. Yue. 2017. RosBREED 2: Progress and future plans to enable DNA-informed breeding in the Rosaceae. In: XIV EUCARPIA Symposium on Fruit Breeding and Genetics 1172:115-118.

Iezzoni, A., C. Weebadde, J. Luby, C.Y. Yue, C.P. Peace, N. Bassil, and J. McFerson. 2010. RosBREED: Enabling marker-assisted breeding in Rosaceae. Acta Hort. 859:389-394.

Iezzoni, A., C. Weebadde, C. Peace, D. Main, N. Bassil, M. Coe, G. Fazio, K. Gallardo, K Gasic, J. Luby, J. McFerson, E. van de Weg, and C. Yue. 2016. Where are we now as we merge genomics into plant breeding and what are our limitations? Experiences from RosBREED. Acta Hort. 1117:1-6.

Jung, S., T. Lee, C. Cheng, K. Buble, P. Zheng, J. Yu, J. Humann, S.P. Ficklin, K. Gasic, K. Scott, M. Frank, S. Ru, H. Hough, K. Evans, C. Peace, M. Olmstead, L.W. DeVetter, J. McFerson, M. Coe, J.L. Wegrzyn, M.E. Staton, A.G. Abbott, and D. Main. 2019. 15 Years of GDR: New data and functionality in the genome database for Rosaceae. Nucl. Acids Res. 47:D1137-D1145.

Lerceteau-Köhler, E., G. Guerin, and B. DenoyesRothan. 2005. Identification of SCAR markers linked to Rca 2 anthracnose resistance gene and their assessment in strawberry germplasm. Theor. Appl. Genet. 111:862-870.

Mangandi, J., S. Verma, L. Osorio, N.A. Peres, E. van de Weg, and V.M. Whitaker. 2017. Pedigree-based analysis in a multiparental population of octoploid strawberry reveals QTL alleles conferring resistance to Phytophthora cactorum. G3 (Bethesda) 7:1707-1719.
Mathey, M.M. 2013. Phenotyping diverse strawberry (Fragaria spp.) germplasm for aid in marker-assisted breeding, and marker-trait association for red stele (Phytophthora fragariae) resistance marker Rpf1. Master's thesis, Oregon State University, Corvallis, OR.

Nellist, C.F., R.J. Vickerstaff, M.K. Sobczyk, C. Marina-Montes, F.M. Wilson, D.W. Simpson, A.D. Whitehouse, and R.J. Harrison. 2019. Quantitative trait loci controlling Phytophthora cactorum resistance in the cultivated octoploid strawberry (Fragaria $\times$ ananassa). Hort. Res. 6:60.

Noh, Y.H., S. Lee, V.M. Whitaker, K.R. Cearley, and J.S. Cha. 2017. A high-throughput markerassisted selection system combining rapid DNA extraction high-resolution melting and simple sequence repeat analysis: Strawberry as a model for fruit crops. J. Berry Res. 7:23-31.

Noh, Y.H., Y. Oh, J. Mangandi, S. Verma, J.D. Zurn, Y.T. Lu, Z. Fan, N. Bassil, N. Peres, G. Cole, and C. Acharya. 2018. High-throughput marker assays for $F a R P c 2$-mediated resistance to Phytophthora crown rot in octoploid strawberry. Mol. Breed. 38:104.

Peace, J. 2017. DNA-informed breeding of rosaceous crops: Promises, progress and prospects. Hort. Res. 4:17006.

Perrotte, J., A. Gaston, A. Potier, A. Petit, C. Rothan, and B. Denoyes. 2016. Narrowing down the single homoeologous FaPFRU locus controlling flowering and fruit production in the cultivated octoploid strawberry using a selective mapping strategy. Plant Biotechnol. J. 14:2176-2189.

Roach, J.A., S. Verma, N.A. Peres, A.R. Jamieson, W.E. van de Weg, M.C. Bink, N.V. Bassil, S. Lee, and V.M. Whitaker. 2016. FaRXf1: A locus conferring resistance to angular leaf spot caused by Xanthomonas fragariae in octoploid strawberry. Theor. Appl. Genet. 129:1191-1201.

Rugienius, R., T. Siksnianas, V. Stanys, D. Gelvonauskiene, and V. Bendokas. 2006. Use of RAPD and SCAR markers for identification of strawberry genotypes carrying red stele (Phytophtora fragariae) resistance gene Rpfl. Agron. Res. 4:335-339.

Salinas, N., S. Verma, N. Peres, and V.M. Whitaker. 2018. FaRCal: A major subgenomespecific locus conferring resistance to Colletotrichum acutatum in strawberry. Theor. Appl. Genet. 132(4):1109-1120.

Salinas, N.R., J.D. Zurn, M. Mathey, S. Mookerjee, B. Denoyes, J. Perrotte, A. Potier, C.E. Finn, J.F. Hancock, P. Stewart, and N.V. Bassil. 
2017. Validation of molecular markers associated with perpetual flowering in octoploid Fragaria germplasm. Mol. Breed. 37:70.

Sánchez-Sevilla, J.F., E. Cruz-Rus, V. Valpuesta, M.A. Botella, and I. Amaya. 2014. Deciphering gamma-decalactone biosynthesis in strawberry fruit using a combination of genetic mapping, RNA-Seq and eQTL analyses. BMC Genomics 15:218.

Sasnauskas, A., R. Rugienius, D. Gelvonauskiene, I. Zalunskaite, G. Staniene, T. Siksnianas, V. Stanys, and C. Bobinas. 2007. Screening of strawberries with the red stele (Phytophthora fragariae) resistance gene Rpfl using sequence specific DNA markers. Acta Hort. 760:165169.

van de Weg, W.E. 1997. A gene-for-gene model to explain interactions between cultivars of strawberry and races of Phytophthora fragariae var. fragariae. Theor. Appl. Genet. 94:445-451.

van Geest, G. 2017. Disentangling hexaploid genetics: Towards DNA-informed breeding for postharvest performance in chrysanthemum. $\mathrm{PhD}$ Diss. Gelderland, Netherlands.

Verma, S., J.D. Zurn, N. Salinas, M.M. Mathey, B. Denoyes, J.F. Hancock, C.E. Finn, N.V. Bassil, and V.M. Whitaker. 2017. Clarifying sub-genomic positions of QTLs for flowering habit and fruit quality in U.S. strawberry (Fragaria Xananassa) breeding populations using pedigree-based QTL analysis. Hort. Res. 4:17062.

Zorrilla-Fontanesi, Y., J. Rambla, A. Cabeza, J.J. Medina, J.F. Sánchez-Sevilla, V. Valpuesta, M.A. Botella, A. Granell, and I. Amaya. 2012. Genetic analysis of strawberry fruit aroma and identification of o-methyltransferase $\mathrm{FaOMT}$ as the locus controlling natural variation in mesifurane content. Plant Physiol. 159:851870. 